\title{
Geological modelling of a reservoir analogue: Cenozoic meander belts, Loranca Basin, Spain
}

\author{
M. Díaz-Molina ${ }^{1}$, J. Arribas ${ }^{2}$, J. J. Gómez ${ }^{1}$ and A. Tortosa ${ }^{2}$ \\ ${ }^{1}$ Departamento de Estratigrafía (UCM), Instituto de Geología Económica (CSIC), Facultad de Ciencias Geológicas, \\ 28040 Madrid, Spain. \\ ${ }^{2}$ Departamento de Petrología y Geoquímica (UCM), Instituto de Geología Económica (CSIC), \\ Facultad de Ciencias Geológicas, 28040 Madrid, Spain.
}

\begin{abstract}
The reconstruction of meander belts was approached by detailed geological mapping, the interpretation of exposed sandstone bodies and the application of sedimentological concepts. The single reconstructed meander belts were integrated, considering stratigraphic position and thickness in a threedimensional model of the depositional architecture. Some useful reservoir parameters, such as volume of meander loops, areas of interconnection and fluid flow barriers, are calculated from the obtained model. Sandstone porosity is mainly of primary origin and mechanical compaction is the most intense diagenetic feature. Models of estimated permeability evolution in the point bar sequences have been developed. Gamma ray readings from different lithologies were obtained and grouped according to their palaeoenvironmental classification. The results are comparable to well logs and aid subenvironmental characterization of continental deposits.
\end{abstract}

KEYWORDS: fluvial geometry, flow barriers, porosity, permeability

Modelling the sedimentary geometry of hydrocarbon reservoirs currently represents one of the most important challenges for the oil industry. Predictions are required for the external and internal geometry of the reservoirs, as well as of the distribution of porosity, permeability, fluid-flow barriers and pay intervals. Such predictions are especially critical for reservoir deposits in environments where the distribution and continuity of the sand bodies can be highly complex (e.g. Barwis et al. 1990). This is the case in meandering stream systems, which form excellent reservoirs but frequently have puzzling three-dimensional distributions of the different parameters. Study of the wealth of information provided by good surface outcrops can assist in understanding subsurface reservoirs. In this article we describe the geology of such an example, the Tertiary meander belts exposed in the Loranca Basin, central Spain.

\section{GEOLOGICAL SETTING}

The Loranca Basin (Fig. 1) contains thick Cenozoic continental deposits. The studied meander belt sediments are included in the 'Upper Unit', composed of the Tórtola and Villalba de la Sierra coalescent depositional systems (Fig. 1), of Late Oligocene to Early Miocene age (Díaz-Molina et al. 1989). The fluvial fan systems were formed during tectonic deformation, with progressive unconformities on the flanks of growing anticlinal folds. At the top of the Upper Unit, in Early Miocene times, gypsum deposits covered most of the basin.

Based on surface, seismic and drill hole data, the area is known to contain a north-trending, thin-skin thrust belt vergent to the west; Mesozoic and a part of the Tertiary strata

Presented at the EAPG Conference, June 1992, Paris. are deformed. Regional seismic lines show that Mesozoic and Tertiary strata are detached from Palaeozoic basement and Permo-Triassic tegument at the level of Triassic salt (Keuper). Folding and salt migration into the cores of the anticlinal structures generated primary synclines as well as secondary rim synclines in some areas. These structures, coupled with faulting, controlled the distribution of facies (i.e. fluvial palaeocurrents) as well as the location of depocentres.

Meander belt sediments were studied on the east flank of the Huete ramping anticline, north of the Huete village. For reservoir characterization, a $640 \mathrm{~m}$ long by $130 \mathrm{~m}$ thick crosssection was studied in detail (Fig. 2). Lithologies include sandstones, mudstones, limestones, gypsiferous silts and gypsum. Two thin, continuous, limestone layers are present. The upper one divides the cross section into two portions. The upper portion is characterized by the presence of gypsum as crystals in mudstone or as cement in sandstones, whilst in the lower portion gypsum is virtually absent.

The studied section has been buried beneath only $200 \mathrm{~m}$ of sediments; the overburden was low enough so that sandbody geometries are generally well preserved. Correction of differential compaction between silty clays and sandstones allowed the restoration of syn-sedimentary fluvial architecture.

\section{DEPOSITIONAL ENVIRONMENTS}

\section{Floodplain elements}

The landscape was often dominated by meandering rivers, with meander loops, abandoned meandering channels, channel-fills, crevasse splays, levees and flood basin deposits. Abandoned meandering channels are filled with a wide variety 


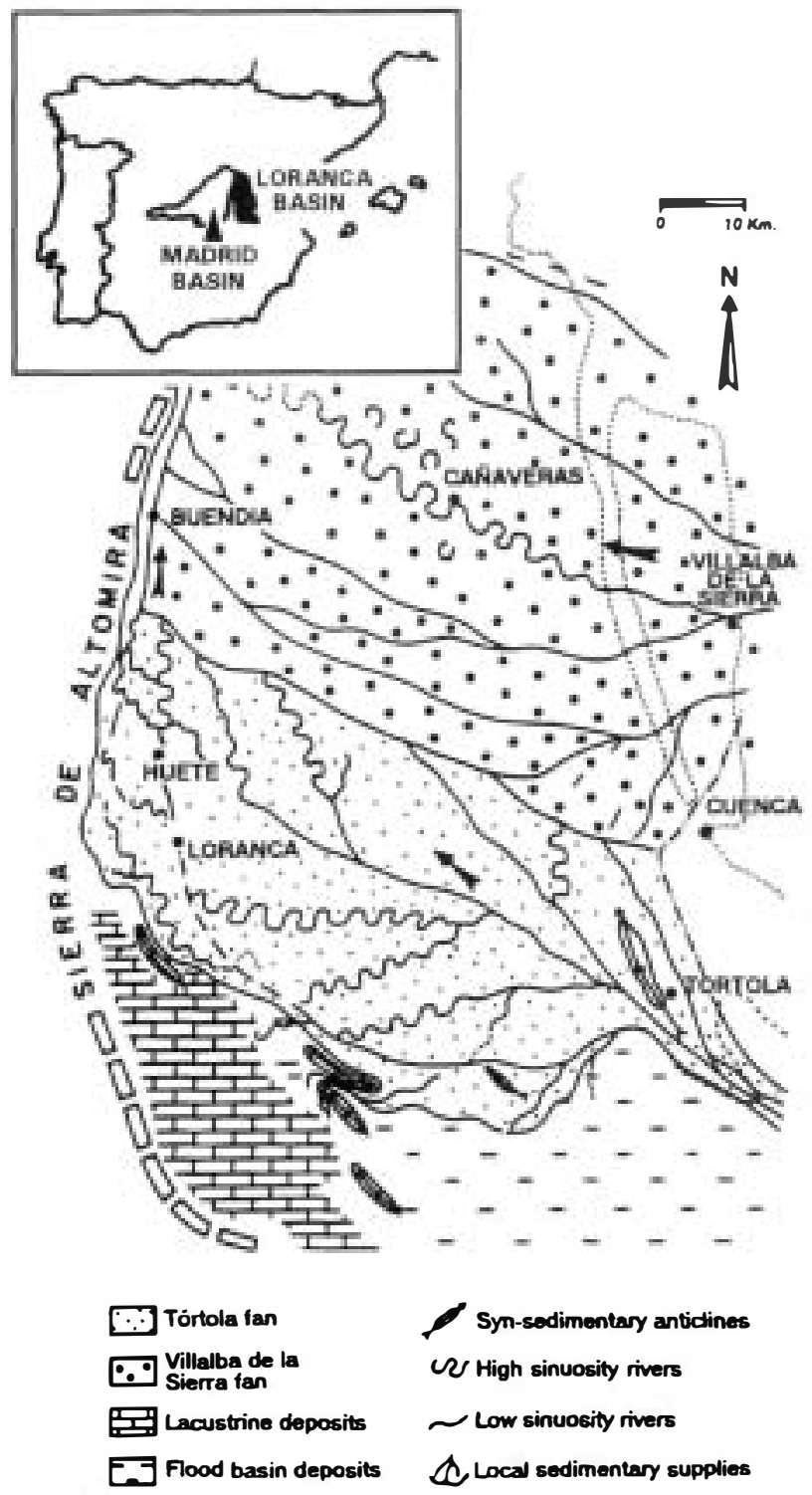

Fig. 1. Location map of the Loranca Basin with facies distribution of the Tôrtola and Villalba de la Sierra depositional systems (Díaz-Molina et al. 1989).

of facies which frequently grade up into lacustrine deposits. Channel-fill deposits include sandy fillings in non-meandering channels, probably associated with crevassing. Overbank marginal deposits consist of sheet-like, fine-grained sediments that may show an erosional base. Levees are recognized on the basis of their triangular geometry in cross section and/or their position over the outer meandering channel bank.

Most flood basin deposits consist of massive silty clays with subordinate lacustrine marls and/or limestones, that represent the most important permeability barriers within a reservoir system. In the upper part of the cross-section the silty clays have been interpreted as playa-lake sediments as they contain gypsum crystals (Díaz-Molina et al. 1989; Arribas-Mocoroa et al. 1991). Palaeosols (entisols and calcretes) are frequently developed at the top of abandoned channels and over marginal lacustrine and overbank deposits.

Meander loop deposits are the most common potential reservoir sands and form in isolated or connected point bar bodies. Reactivation surfaces separate adjacent point bars as well as different stages in the evolution of the meander loops.
They are internal unconformities shown by erosion and changes in grain size. They formed by adjustment of the channel shape once the critical curvature threshold was reached (Díaz-Molina 1993). Identification of the reactivation surfaces is indispensable for reconstruction of meander loops and palaeochannel trends.

Meander loop width and depth depend on palaeochannel size. The lateral extent of the meander loops was also controlled by meander amplitude and the lateral juxtaposition of point bar bodies. In the studied cross-section (Fig. 2), meander loop width ranges between $495 \mathrm{~m}$ and $12.5 \mathrm{~m}$, and their thickness varies between $3.25 \mathrm{~m}$ and $9.15 \mathrm{~m}$.

\section{Point bar facies}

The term point bar is used here to indicate a composite bar formed by a set of conformable lateral accretion units (DíazMolina et al. 1989), which correspond with a group of parallel scroll bars in a plan view. Two types of point bar sequences are found in the exposures. The less frequent was generated by helicoidal flow, originating vertical changes in sediment grain size and lateral accretion surfaces.

Ripple cross-stratification is the dominant sedimentary structure in $90 \%$ of all point bars. Ripples composed ridge bed forms, showing concave or planar erosional surfaces. Ripple structures that migrated upstream or up and down the point bar topography indicate that flow conditions were not helicoidal (Nanson 1980). Spiral vortices could explain the opposing flow directions and could have produced the concave erosional troughs observed inside these deposits (Fig. $3 \mathrm{~A}$ and B). Troughs between ridge crests may present lag deposits, consisting of intrabasinal clasts. Composite bars delimited by flat surfaces (Fig. $3 \mathrm{C}$ ) would correspond to sections parallel to flow vortices.

\section{THREE-DIMENSIONAL ARCHITECTURE}

Meander loop portions were identified by facies analysis, assisted by comparison with available geometrical models (Díaz-Molina 1993). Using this, and applying sedimentological concepts, the wave lengths, radii of curvature and amplitude of the meanders were reconstructed on enlarged aerial photographs (scale 1:2140). When enough data were available, the positions of buried or eroded meander loops were predicted. Fitting the sandstone exposures into 18 reconstructed meander belts helped to determine palaeochannel trends. The methodology followed for the reconstruction of meander belts is explained in Fig. 4. In some of the reconstructed examples measures of meander wave length were obtained, ranging between $195 \mathrm{~m}$ and $385 \mathrm{~m}$.

The mapping identified 43 meander loops. Using their stratigraphic position and thickness, a three-dimensional reconstruction was made showing the depositional architecture of superimposed meander belts. The geometric forms for each meander loop were idealized, the plan contour of each body was approximated to a polygon and the thickness was supposed constant. Meander loops can be modelled as right prisms with parallel bases, whose volumes are greater than those of the original sandstone bodies.

The coordinates of the prisms were compiled in a file of geometrical data which was processed in a CAD computer program allowing 3D views of the potential reservoir sandbodies (Fig. 5) and the geometrical inspection of the 3D architecture. Sandstones represent less than 17\% of total volume. The overlap areas constitute only $15 \%$ of the prism basal surfaces. 


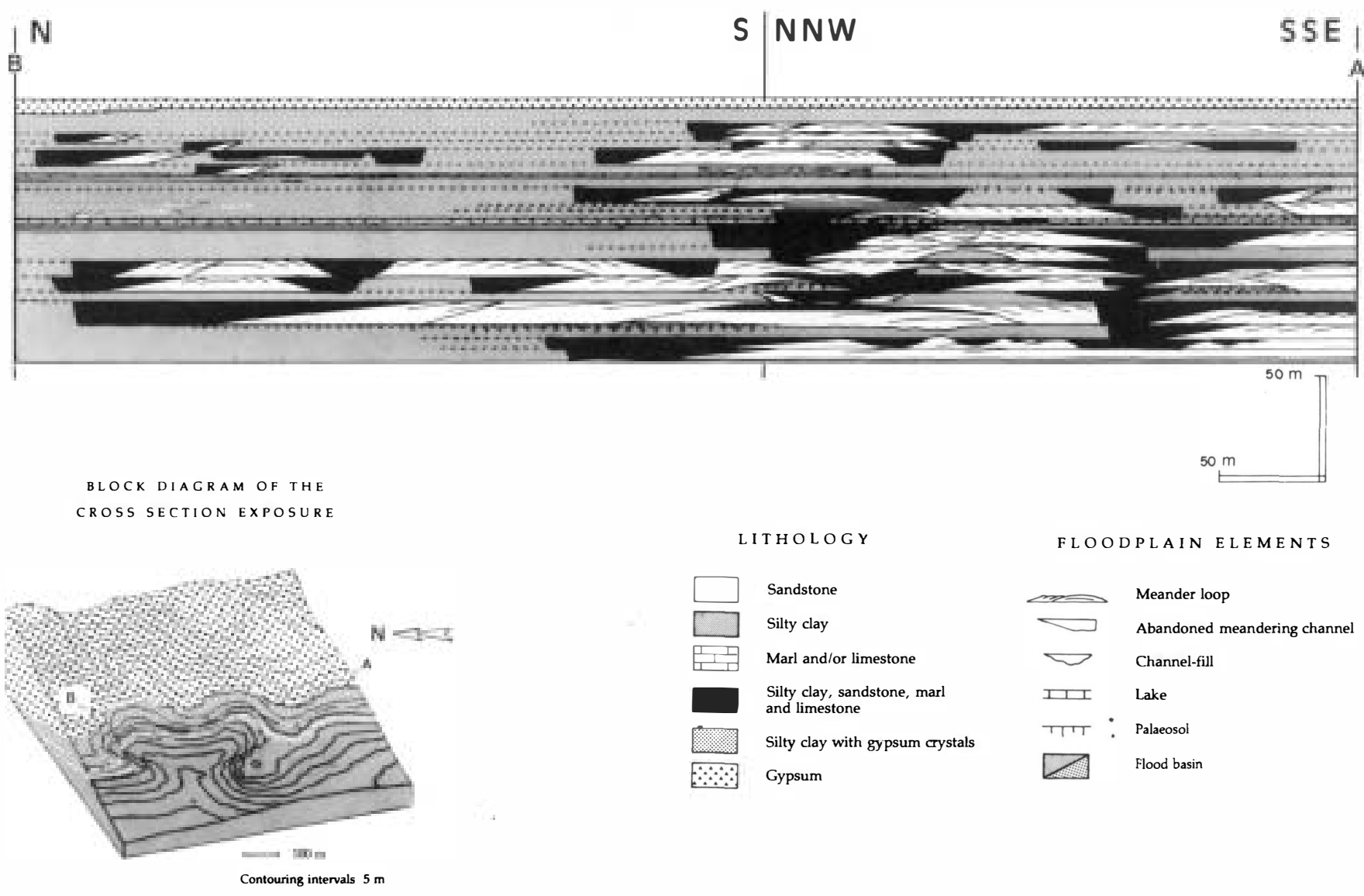

Fig. 2. Cross-section along the Mayor River Valley. Conditioned by topography, successive meander belts were cut along selected parallel directions displacing to the east.

\section{PETROLOGY AND PETROPHYSICS}

The sandstones are lithoarenites mainly composed of moderately to well sorted quartz and sedimentary carbonate rock fragments. Intrabasinal carbonate components are concentrated in channel lags, internal erosional surfaces delimiting ridge structures and in specific foreset laminae.

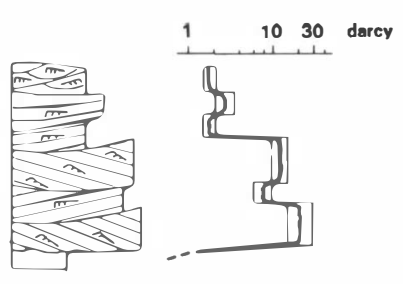

A

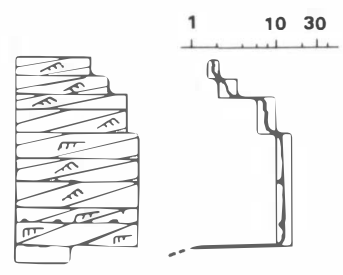

C

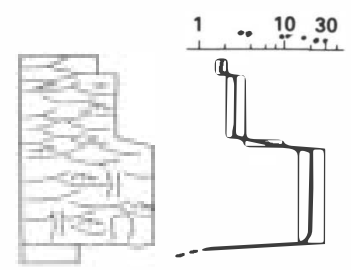

B

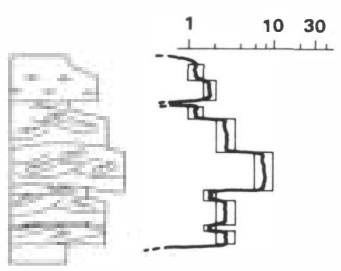

D
Fig. 3. Examples of point bar sequences built up by ridge structures. Only in sequence D have ridge bed forms been preserved. Logs of estimated permeability are shown with standard deviations represented as rectangles.
The framework composition suggests a recycling from Mesozoic sedimentary rocks in the Iberian Range. Diagenesis is not intense and consists mainly of calcite and gypsum cementation and compaction. In the lower section, only calcite cement $(<10 \%)$ appears, while gypsum is the dominant cement type (20 to $30 \%$ ) in the upper section, completely occluding primary pores. Variation in cement mineralogy up-section is related to the increase in groundwater salinity during deposition (Díaz-Molina et al. 1989). Compaction has deformed the micritic grains so reducing primary porosity. Micritic grains played a decisive role in the porosity reduction of sandstones in the lower section. The total thickness reduction of sandstone bodies caused by compaction has been estimated to be $27 \%$ and $15 \%$ in the lower and the upper section, respectively.

Porosity varies up to $30 \%$. Primary porosity is represented best in the lower part (5-25\%) with intergranular macropores $(0.5-0.06 \mathrm{~mm})$. In this part of the section, secondary porosity ( $<5 \%$ ) appears mainly as oversized pores generated by dissolution of carbonate grains. In the sandstones the average size of primary pores is directly related to the average size of pore-forming grains (nearly $1 \phi$ smaller than grains), as shown by Hartkamp et al. (1993). These authors also found that sandstone permeability (0.5-20 D), measured in outcrops with a probe permeameter, is mainly a function of pore size. Therefore, given the significance of these petrographical parameters, permeability values can be estimated (Fig. 3). A general decrease in permeability occurs up-sequence. Vertical fluctuations in permeability trends are directly related to sequence type, being more frequent in types A and D (Fig. 3). Thus, fluctuations in grain size may even create vertical 
1. STRATIGRAPHIC CORRELATION AND MAPPING

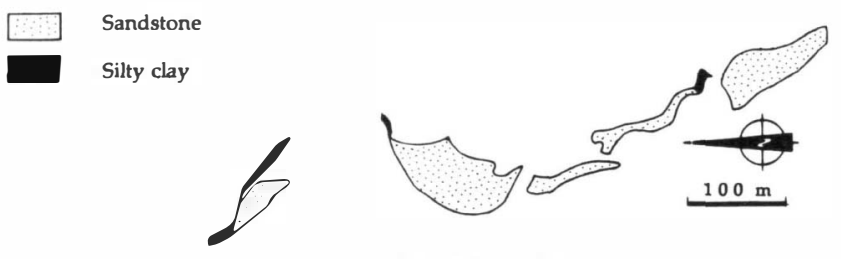

2. FACIES ANALYSIS

Exd Exposure interpretation

a. Dip and strike of the lateral accretion units

1. Meander radius of curvature

Channel $\downarrow$ Channel local trend

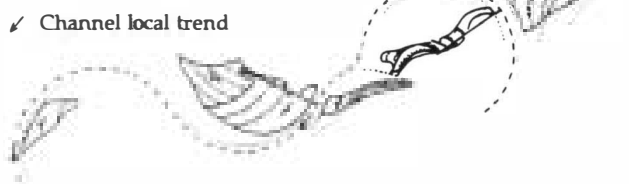

3. MEANDER BELT RECONSTRUCTION

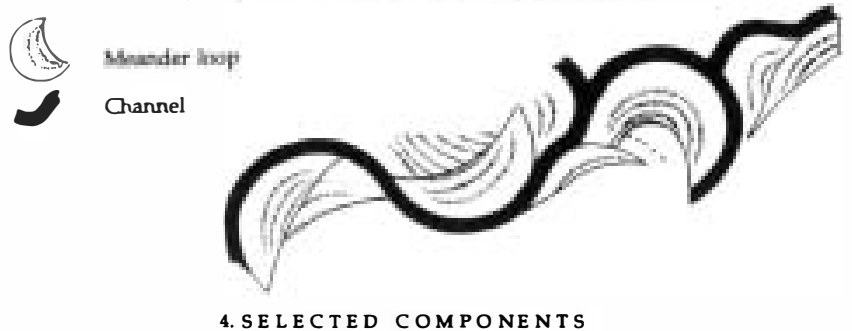

Sandstone
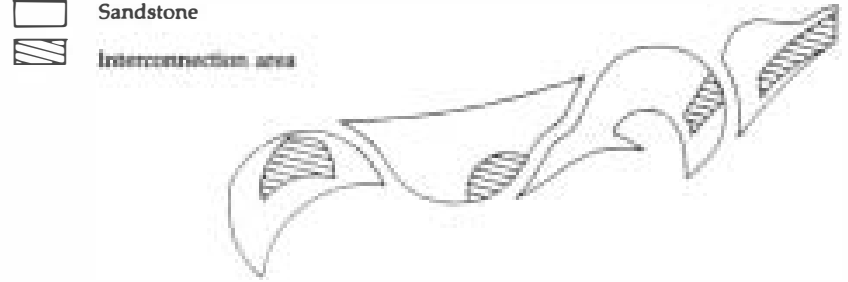

Fig. 4. Stages in the reconstruction of a meander belt. (1) Exposure map showing the outcrops of the different lithologies. (2) Facies analysis allowed interpretation of meander loop portions. (3) Meander belt reconstruction. Superposition of reconstructed meander belts allowed mapping of the areas in which successive sandbodies are vertically connected (4).

permeability barriers on a point bar sequence scale. Although the framework lithology has not been considered in permeability estimation, concentration of intrabasinal micritic pebbles between ridge structures and in certain foreset

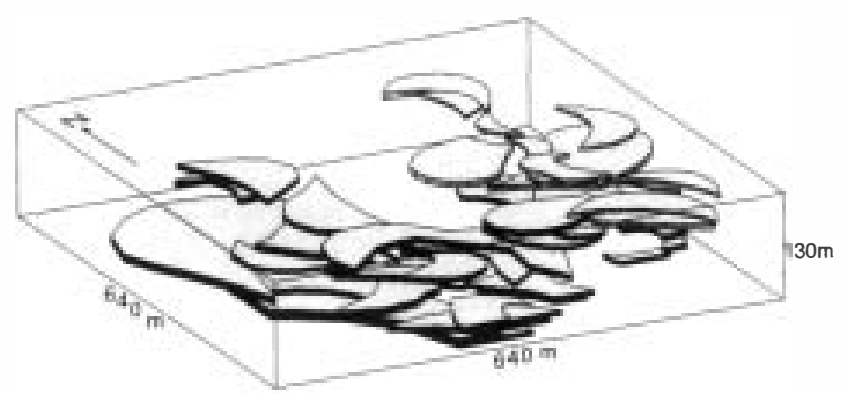

Fig. 5. Three-dimensional reconstruction of fluvial architecture in the studied area. The 3D model shows the complex distribution of potential reservoir sands in this type of environment. Deflection in palaeochannel deposits reflects the growth of the Huete ramping anticline. Northwest orientations of palaeochannel trends in the lower portion, change to north-orientated upwards trends, parallel to the Huete fold. laminae could produce additional vertical and horizontal heterogeneities in reservoir quality, due to compactional effects.

Lateral variations in permeability across a point bar section, occur within and between the ridges (Fig. 6). Ridge margins are generally fine-grained and the highest values of permeability are confined to the centres of the ridges. On the other hand, grain size varies from one ridge to another causing important heterogeneities in permeability across the meander loops. In the case represented in Fig. 6, ridges forming the central part of the meander loop show the lowest permeability values. The irregular grain size distribution in a ridge makes predictions about permeability in meander loops hazardous. In other words, the meander loops studied facies cannot be considered as homogeneous units in the characterization of a similar potential reservoir.

\section{GAMMA RAY LOG}

Gamma ray readings from lithologies representative of the different sedimentary environments were obtained by using a scintillometer and were statistically processed (Fig. 7). Standard deviations for the different types of facies are small, except for the lacustrine deposits, where the mixture of lithologies (limestones, marls some times with abundant organic matter, marls with gypsum crystals, etc.) gives a higher dispersion of radioactivity. Highest mean values were recorded in the flood basin deposits and lowest values in the gypsum deposits.

Most facies show sufficiently characteristic gamma ray signatures to allow discrimination between them. To illustrate this, a synthesized stratigraphic succession of the different facies types was constructed along with the mean gamma ray values to simulate a gamma ray log (Fig. 8). A clay line corresponds to the highest gamma ray values (c. 145 counts per second (CPS)) in the silty clay deposits corresponding to flood basin sedimentary environments. A sand line (for point bar lithoarenites without gypsum) occurs in the central portion of the $\log$ (c. $100 \mathrm{CPS}$ ). Beds with gypsum in the upper section show lower radioactivity than their non-gypsiferous equivalents. Thus, the almost impermeable point bar sandstones with gypsum have CPS values lower than expected.

\section{ASSESSING RESERVOIR ARCHITECTURE}

Reconstruction of the three-dimensional architecture of these meander belt deposits has shown a complex sandstone distribution. This complexity is caused by vertical changes in palaeochannel trends and hydromorphological variables that control the scattered locations of meander loops, their thickness, meander amplitude and meander wave length.

The meander loop bodies described here are small compared with productive meander belt reservoirs described by Hastings (1990) and Werren et al. (1990). The biggest meander loop found in the studied area can be inscribed within a right prism with a total volume of $4.36 \times 10^{5} \mathrm{~m}^{3}$. Since individual meander loops are small, potential reservoir volume could be improved by the vertical stacking of sandstones. However, even in areas with concentrations of sandstone bodies, only $15 \%$ of the total basal surfaces of the prisms represent areas of interconnection, and the calculated total volume of vertically interconnected prisms does not exceed $1.057 \times 10^{6} \mathrm{~m}^{3}$. These values show that the Loranca meander belts would be too small to be a commercial hydrocarbon reservoir. However, the geometry of our 3D model can be considered as a norm since all meander bends 


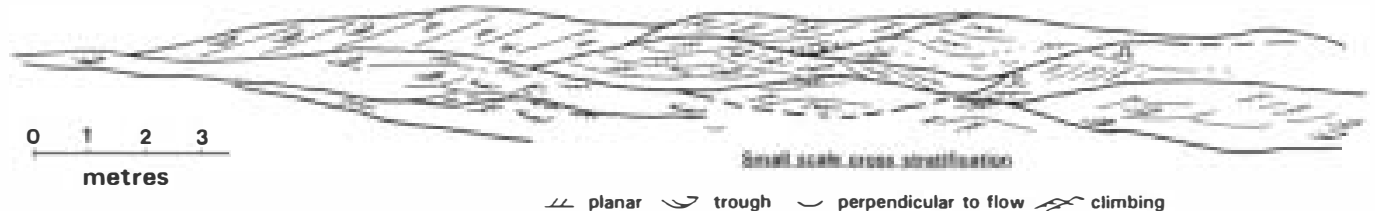

$\Perp$ planar $\smile$ trough $\smile$ perpendicular to flow

\section{B Grain size distribution}

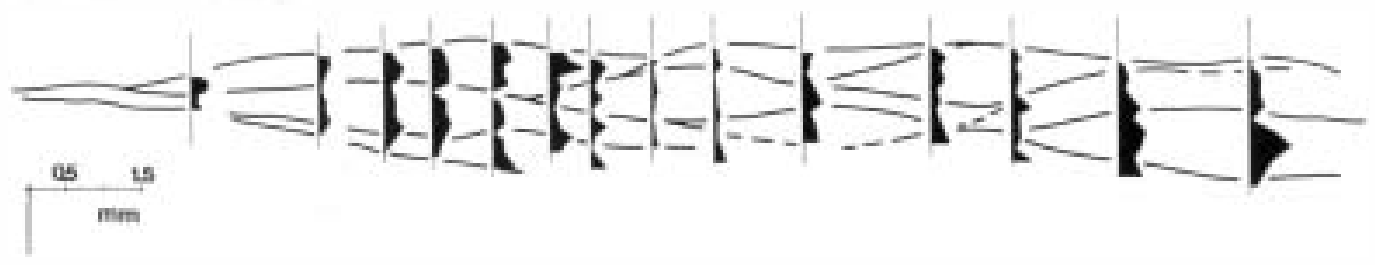

\section{Permeability (estimated)}

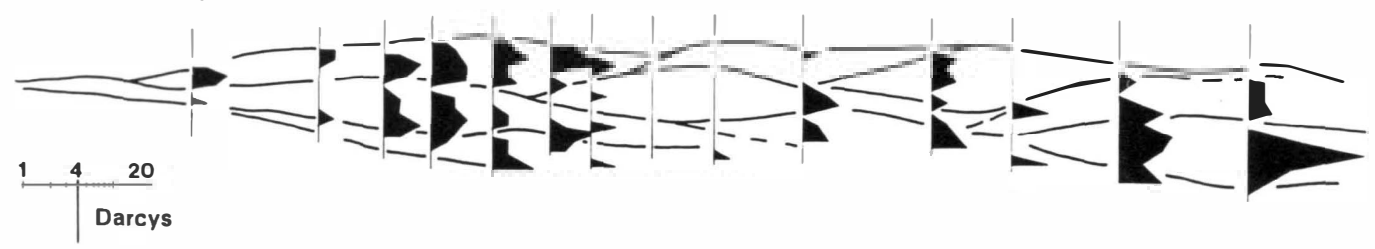

Fig. 6. Bed forms, grain size and permeability distribution in a point thar dominated by ridges. (A) Cross-section of point bar where partially preserved ridges exhibiting point bar sequences of the D type are the dominant bed forms; (B) textural logs showing grain size distribution throughout the point bar body; (C) estimated permeability logs obtained from grain size distribution data.

are of proportional size (Leopold \& Wolman 1960). For instance, bigger river systems develop larger meander loops, but overlap areas can represent a similarly low percentage of the basal surfaces of the meander loops.

Moreover, the 3D model can be used as a predictor in fluvial

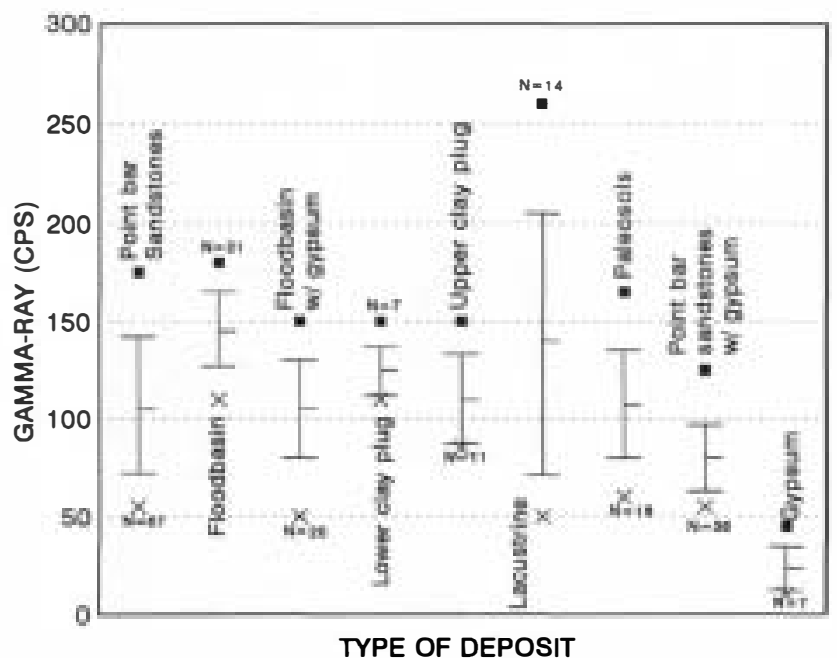

Fig. 7. Statistical distribution of gamma ray readings for deposits representative of the different sedimentary environments. Squares and crosses respectively represent maximum and minimum recorded values. Extreme segments of the bars respectively represent the values of the upper and lower standard deviation. Segments in the central portion of the bars are the mean values. N: number of readings; CPS: counts per second. successions of Late Oligocene-Early Miocene age, deposited in a similar climate, and where the effects of subsidence, width of the basin, and size of the catchment area can be inferred. In a narrower basin, discharge and channel concentration would produce thicker porous rock bodies and a relatively higher content of interconnected sandstones than that observed in the Loranca Basin.

Heterogeneities representing probable fluid flow barriers occur at different scales. Major discontinuities are caused by the flood basin silty clays which serve to isolate nonamalgamated meander loops. Other discontinuities are represented by the overlap surfaces between stacked meander loop bodies, as well as by the reactivation surfaces separating point bar bodies. At a more detailed scale, other internal heterogeneities are represented by the lateral decrease of grain size between lateral accretion units.

Inside the sandstones, two other sources of heterogeneity affect permeability values. Soft pebbles occur at the base of trough erosional surfaces. Changes in grain size occur between ridge structures, especially when very fine sand to silt at the top of the ridges is preserved from erosion. When ridges are preserved, multiple and amalgamated sand ribbons may occur around the meander bend, which would complicate fluid flow. Such deleterious effects on reservoir quality are not restricted to small channels because flow separation in meander bends is a function of bend tightness and Froude number, which have similar effects in big rivers (Leeder $\&$ Bridges 1975).

This research was funded in part by the Commission of the European Communities in the framework of the Joule Programme (1990-1993), Sub-programme: Hydrocarbons. 


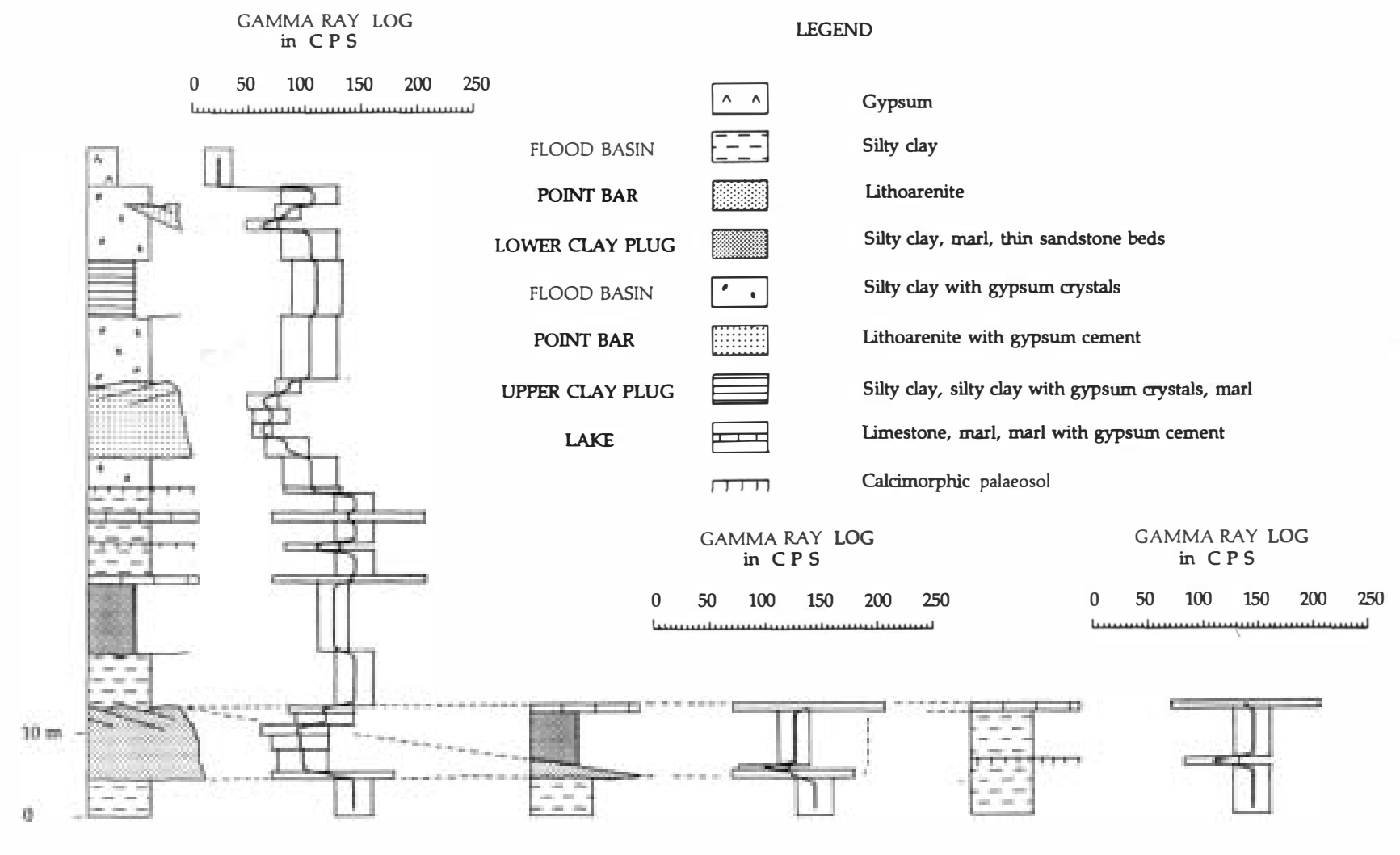

Fig. 8. Synthesized stratigraphic log, showing lithologies and interpreted environments as well as a gamma ray log obtained from scintillometer readings in the field. Rectangles in the gamma ray log represent the value of the standard deviation corresponding to the gamma ray readings in counts per second (CPS). The gamma ray log was traced by following the mean values of the gamma ray readings for each type of deposit.

\section{REFERENCES}

ARRIBAS-MOCOROA, J., BUSTILLO, M. A \& DíAZ-MOLINA, M. 1991. Chert in bioturbated sediments of sabkha paleoenvironment. V Flint International Symposium, Madrid-Bilbao-Granada. Abstracts, 29-33.

BARWIS, J. H., McPHERSON, J. G. \& STUDLICK, J. R. J. (eds) 1990. Sandstone Petroleum Reservoirs. Springer-Verlag, Berlin.

DíAZ-MOLINA, M. 1993. Lateral accretion patterns in ancient meander loops, Loranca Basin, Central Spain. In: International Association of Sedimentologists, Special Publication, 17, 115-131.

—, ARRIBAS-MOCOROA, J. \& BUSTILLO-REVUELTA, A. 1989. The Tórtola and Villalba de la Sierra fluvial fans: Late Oligocene-Early Miocene, Loranca Basin, Central Spain. 4th International Conference on Fluvial Sedimentology, Barcelona-Sitges, Spain. Field Trip 7.

HARTKAMP, C. A., ARRIBAS, J. \& TORTOSA, A 1993. Grain size, composition, porosity and permeability contrasts in cross-bedded sedimentary structures of Tertiary fluvial deposits, central Spain. Sedimentology, 40, 787-799.
HASTINGS Jr., J. O. 1990. Coarse-grained meander-belt reservoirs, Rocky Ridge Field, North Dakota. In: Barwis, J. H., McPherson, J. G. \& Studlick, J. R. J. (eds) Sandstone Petroleum Reservoirs. Springer-Verlag, New York, Berlin, 5784.

LEEDER, M. R. \& BRIDGES, P. H. 1975. Flow separation in meander bends. Nature, 253, 338-339.

LEOPOLD, L. B. \& WOLMAN, M. G. 1960. River Meanders. Bulletin of the Geological Society of America, 71, 769-794.

NANSON, G. C. 1980. Point bar and flood plain formation of the meandering Beatton River, northeastern British Columbia, Canada. Sedimentology, 27, 3-30.

WERREN, E. G., SHEW, R. D., ADAMS, E. D. \& STANCLIFFE, R. J. 1990. Meanderbelt reservoir geology, Mid-Dip Tuscaloosa, Little Creek Field, Mississippi. In Barwis, J. H., Mcpherson, J. G. \& Studlick, J. R. J. (eds) Sandstone Petroleum Reservoirs. Springer Verlag, New York, Berlin, 85-108. 